DOI: $10.2478 / \mathrm{mipo}-2022-0001$

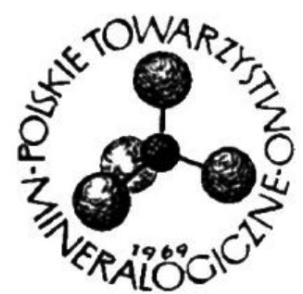

\title{
Mesoarchean melt and fluid inclusions in garnet from the Kangerlussuaq basement, Southeast Greenland
}

\section{Gautier Nicoli ${ }^{1^{*}}$ \\ Kerstin Gresky ${ }^{1}$ \\ Silvio Ferrero ${ }^{2}$}

${ }^{1}$ Universität Potsdam, Institut für Geowissenschaften, Karl-Liebknecht-Str. 24-25, 14476 Potsdam-Golm, Germany ${ }^{2}$ Università degli Studi di Cagliari, Cittadella Universitaria di Monserrato S.S. 554 Bivio Sestu, 09042 Monserrato, Italy

*Corresponding author: nicoli@uni-potsdam.de

\begin{abstract}
The present work reports the first anatectic melt inclusions found so far in the Mesoarchean basement in East Greenland. Using optical microscope observations and MicroRaman spectroscopy, we show that garnets in metasedimentary migmatite contain primary polycrystalline aggregates which can be confidently interpreted as former droplets of anatectic melt, i.e. nanogranitoids. In some cases, they coexist with coeval fluid inclusions under conditions of primary fluid-melt immiscibility. The re-evaluation of the metamorphic pressure and temperature conditions with up-to-date phase equilibria modelling, combined with the identification of nanogranitoids and fluid inclusions, suggests metamorphic peak equilibration and partial melting in presence of a $\mathrm{COH}$-fluid at $\mathrm{T} \sim 1000^{\circ} \mathrm{C}$ and $\mathrm{P}>7 \mathrm{kbar}$. To date, this is the oldest verified occurrence of nanogranitoids and fluid-melt immiscibility during garnet growth in a partially molten environment.
\end{abstract}

Keywords: Melt inclusion, Precambrian, Greeland

\section{Introduction}

Primary crystallised melt and fluid inclusions ( $\mathrm{Ml}$ and $\mathrm{FI}$ ) in metamorphic minerals such as garnet or zircon constitute an invaluable archive to identify and investigate partial melting processes and crustal differentiation (e.g. Cesare et al. 2015; Nicoli, Ferrero 2021). Nicoli and Ferrero (2021) suggested there might be a link between the pesence of $\mathrm{MI}$ and $\mathrm{Fl}$, volatile recycling/reworking in the crust, the evolution of plate tectonics and surface habitability. However, if this correlation works for the Phanerozoic eon, there is a lack of data for the Precam- brian period. The oldest evidence for the remobilisation of volatiles associated with partial melting in the lower continental crust was found in the ca. $2580 \mathrm{Ma}$ Athabasca granulite terrane (Tacchetto et al. 2019).

Here we present new microstructural and metamorphic data on the 2800-3000 Ma basement around the Skaergaard Intrusion (Wager, Deer 1939; Kays et al. 1989), Southeast Greenland. The Mesoarchean (2800$3000 \mathrm{Ma})$ is a crucial period in Earth history. It represents a geodynamic turning point where a net change in crustal growth and reworking rates (Dhuime et al. 2018; Nicoli et al. 2016) evidences the transition from 

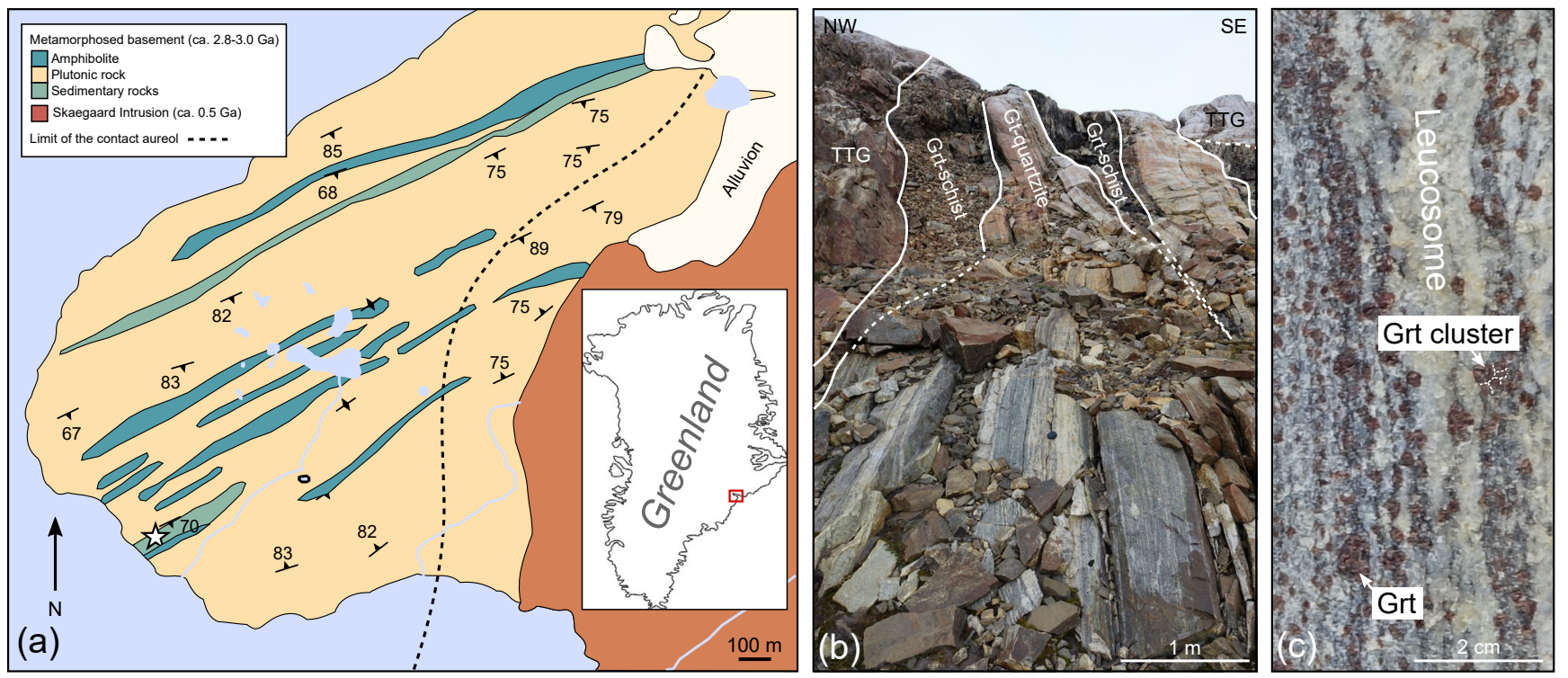

Figure 1. (a) Simplified geological map of the Uttental Plateau, Southeast Greenland. Basement rocks between the Skaergaard Layered Intrusion and the dashed line have been affected by contact metamorphism. Star: sample site. (b) Metasedimentary lens surrounded by TTGs. Classification after Kays et al. (1989). (c) Close-up on the Grt-quartzite where inclusion-bearing garnet (see Fig. 2) forms clusters and overprints the main fabric (D2, D3).

stagnant-lid tectonics to mobile-lid tectonics (Palin et al. 2020). Because of its exceptional exposure, age and pristine aspect, the Mesoarchean lithologies exposed in the Uttental Plateau (Fig. 1a) represent an ideal natural laboratory to investigate crustal reworking processes and the remobilisation of volatile elements (e.g. $\mathrm{H}, \mathrm{C}, \mathrm{N}$ ) in active continental margin during the onset of plate tectonics.

\section{Geological settings}

The Mesoarchean basement exposed in the Kangerlussuaq Fjord, Southeast Greenland, represents a part of the Nagssugtoquidian fold belt which has escaped Proterozoic reworking (Nicoli et al. 2018 and references therein). The basement was first described by Wager (1934), but remains overall relatively unexplored since then. The most extensive tectono-metamorphic study in the area of interest was conducted by Kays et al. (1989) who focused on the structural history and geochemical diversity of the different lithologies around the Watkins Fjord and the Skaergaard Intrusion, notably in the Uttental Plateau (Fig. 1a). More recently Holwell et al. (2013) have investigated gold-bearing quartz veins in exhumed supracrustal units $35 \mathrm{~km}$ north-northeast of the Skaergaard Intrusion. They described the presence of $\mathrm{COH}$-fluids inclusions in quartz $\left(300-350^{\circ} \mathrm{C}\right)$ indicating of the presence of important fluid fluxes associated with devolatilisation reactions during retrograde metamorphism. The basement comprises a fully exposed, typical Archean assemblage of felsic intrusions, TTG and grey gneisses, inter-layered with plurimetric lenses of metasediments and amphibolites, mostly concordant with the main NE-SW trending foliation (Fig. 1b) (Kays et al. 1989). According to Kays et al. (1989) the supracrustal sequence can be divided in four categories: (1) biotite-garnet \pm cordierite schists metapelites; (2) garnet \pm hornblende \pm orthopyroxene-bearing quartzites; (3) metabasic amphibolites and (4) ultramafic rocks pods. The presence of garnet porphyroblasts overprinting the foliation of some of the lithologies suggests that the regional metamorphic event, $650-700^{\circ} \mathrm{C}$ and $3-4$ kbar, occurred in a relative static environment. The only geochronological data available in the area are whole rock ${ }^{207} \mathrm{~Pb} /{ }^{206} \mathrm{~Pb}$ and $\mathrm{Rb}-\mathrm{Sr}$ analyses on the felsic basement, which give a TTG emplacement age and a regional metamorphic age of $2980 \pm 20 \mathrm{Ma}$ and $2860 \pm 40 \mathrm{Ma}$ respectively (Leeman et al. 1976; Kays et al. 1989).

\section{Methods and sample petrography}

The samples were investigated using a polarised light optical microscope (both in reflected and transmitted light). $\mathrm{Fl}$ and former $\mathrm{MI}$ (i.e. nanogranitoids, Bartoli et al. 2016) were measured in eight garnets on one thin and one thick sections. The inclusions were analysed via Micro-Raman spectroscopy using a HORIBA JobinYvon Confocal LabRAM HR 800 at the University of Potsdam (Germany), with grating 300 lines $/ \mathrm{mm}$, slit width $100 \mu \mathrm{m}$, confocal hole $200 \mu \mathrm{m}(\lambda=532 \mathrm{~nm}$, laser power on sample: $2-3 \mathrm{~mW}$ ). Spectra were acquired in the range $100-4000 \mathrm{~cm}^{-1}$ using 3 accumulations of $30 \mathrm{~s}$ each, with spectral resolution of $10 \mathrm{~cm}^{-1}$. Garnet composition was constrained by EMPA using a JEOL JXA-8200 with an acceleration voltage of $15 \mathrm{kV}, 15 \mathrm{nA}$ beam current and a probe diameter of $2 \mu \mathrm{m}$. 

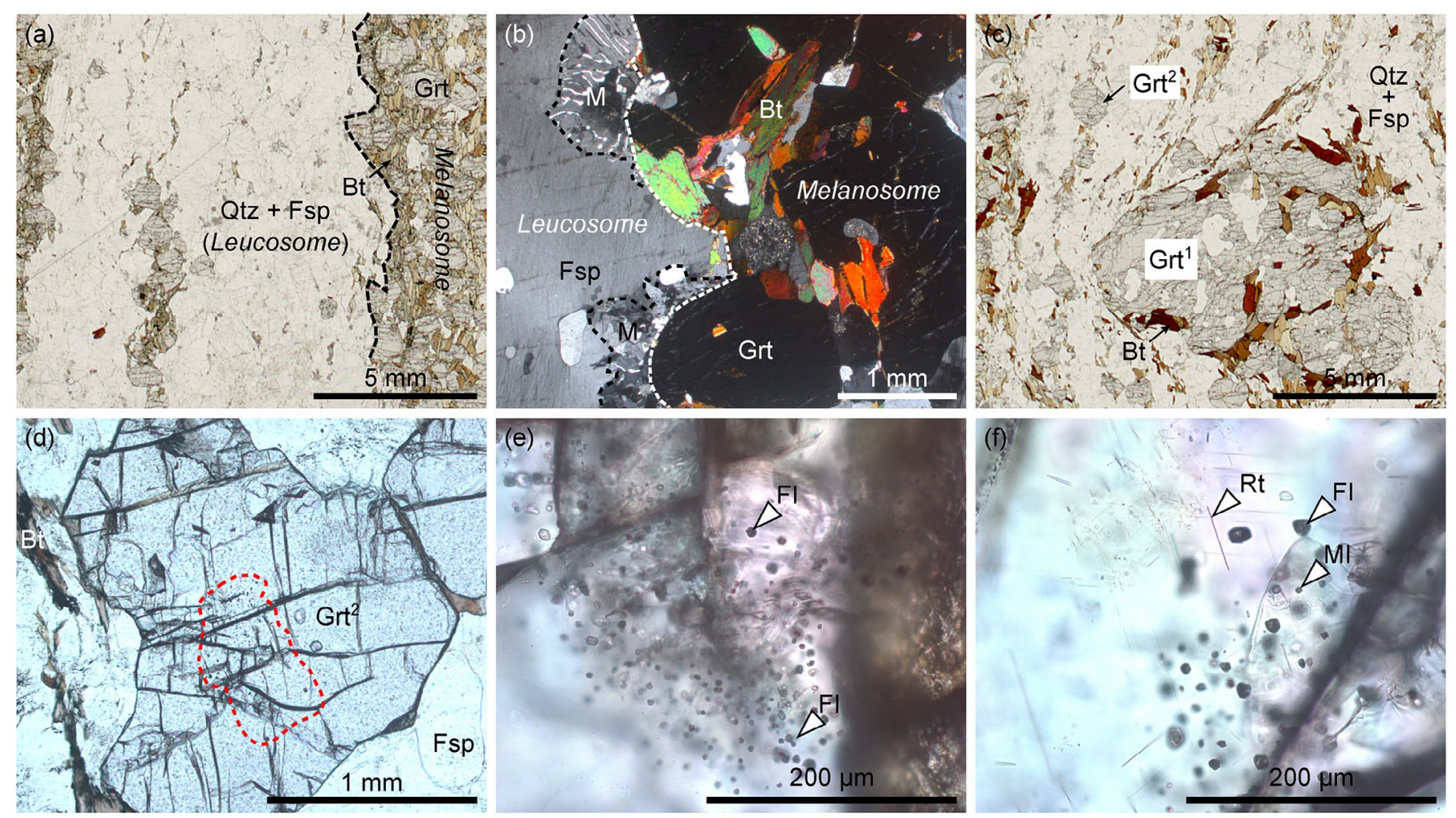

Figure 2. (a) Sample 589590 showing the segregation between the leucocratic and the melanocratic part. (b) Contact between the leucocratic and the melanocratic part marked by the presence of myrmekite (M). (c) Sample 589590 showing the two generations of garnet $\mathrm{Grt}^{1}$ (xenoblastic) and $\mathrm{Grt}^{2}$ (idioblastic). (d) Idioblastic garnet containing a core rich in $\mathrm{COH}$-fluid inclusions delimited by the dashed area. (e) COH-fluid inclusions (FI) in idioblastic garnet. (f) Rutile (Rt), melt (MI) and fluid (FI) inclusions in xenoblastic garnet. Abbreviations after Kretz (1983).

The sample 589590 investigated in this work is a garnet-bearing stromatic migmatite (i.e. described as garnet-quartzite in Kays et al. 1989) sampled from one of the metasedimentary lenses during a field expedition led by the University of Cambridge in 2017. The sampling site is far enough from the Skaergaard Intrusion to prevent any contact metamorphism overprinting (Bufe et al. 2014). The main mineral assemblage consists of garnet, biotite, feldspar, quartz and minor oxides, chlorite, apatite and zircons. Quartz and feldspar are segregated into leucocratic bands (i.e. leucosome - Fig. 1c, Fig. 2a) where feldspar shows serrated grain boundaries, undulatory exsolution and recrystallisation. The melanocratic parts instead mainly consists of garnet and partially chloritised biotite. The alternance of felsic and mafic bands defines the main fabric. Myrmekite occurs at the contact between the melanosome and the leucosome (Fig. 2b). We identified two types of garnets: large xenoblastic garnets $\left(\mathrm{Gr}^{1}\right)$, up to $5 \mathrm{~mm}$ in size, and small idioblastic garnets $\left(\mathrm{Grt}^{2}\right)$ overprinting the main fabric (Fig. 2c), both displaying locally abundant $\mathrm{MI}$ and FI (see following paragraphs).

\section{Results of MI and Fl investigation}

Inclusions of different types, mostly fluid and nanogranitoids, were identified in garnet from the investigated sample. They form clusters in the inner part of the host, a typically primary distribution which support their interpretation as primary fluids trapped during garnet growth (see e.g. Ferrero et al. 2016), rather than infiltrated in cracks during a subsequent stage of rock evolution.

$\mathrm{FI}$ and nanogranitoids can be distinguished in these samples exclusively based on their optical features under microscope observations. Whereas they are both generally isometric in shape (Fig. 2e,f), $\mathrm{Fl}$ are generally up to $40 \mu \mathrm{m}$ in diameter, very dark in appearance under transmitted light due to the presence of graphite and $\mathrm{CO}_{2}$ (see below) - under crossed polars, carbonates can be generally distinguished due to their extreme birefringency. Nanogranitoids are generally smaller (up to $15 \mu \mathrm{m}$ ), have lighter colour in transmitted light and under crossed polars appear to be formed by an aggregate of birefringent phases.

$\mathrm{MI}$ and $\mathrm{Fl}$ occur in both types of garnets, $\mathrm{Grt}^{1}$ and $\mathrm{Grt}^{2}$, which show different microstructural features (Fig. 2c). Large garnets $\left(\mathrm{Grt}^{1}\right)$ contain monomineralic inclusions of quartz, feldspar and biotite, along with scattered nanogranitoids randomly distributed in the garnet, a limited number of fluid inclusions and rutile needles (Fig. 2f). Small garnets ( $\left.\mathrm{Grt}^{2}\right)$ have clusters composed of mainly $\mathrm{Fl}$ (up to $30 \mu \mathrm{m}$, Fig. $2 \mathrm{~d}, \mathrm{e}$ ) along with a minor amount of nanogranitoids, at their core. In both gar- 
(a)
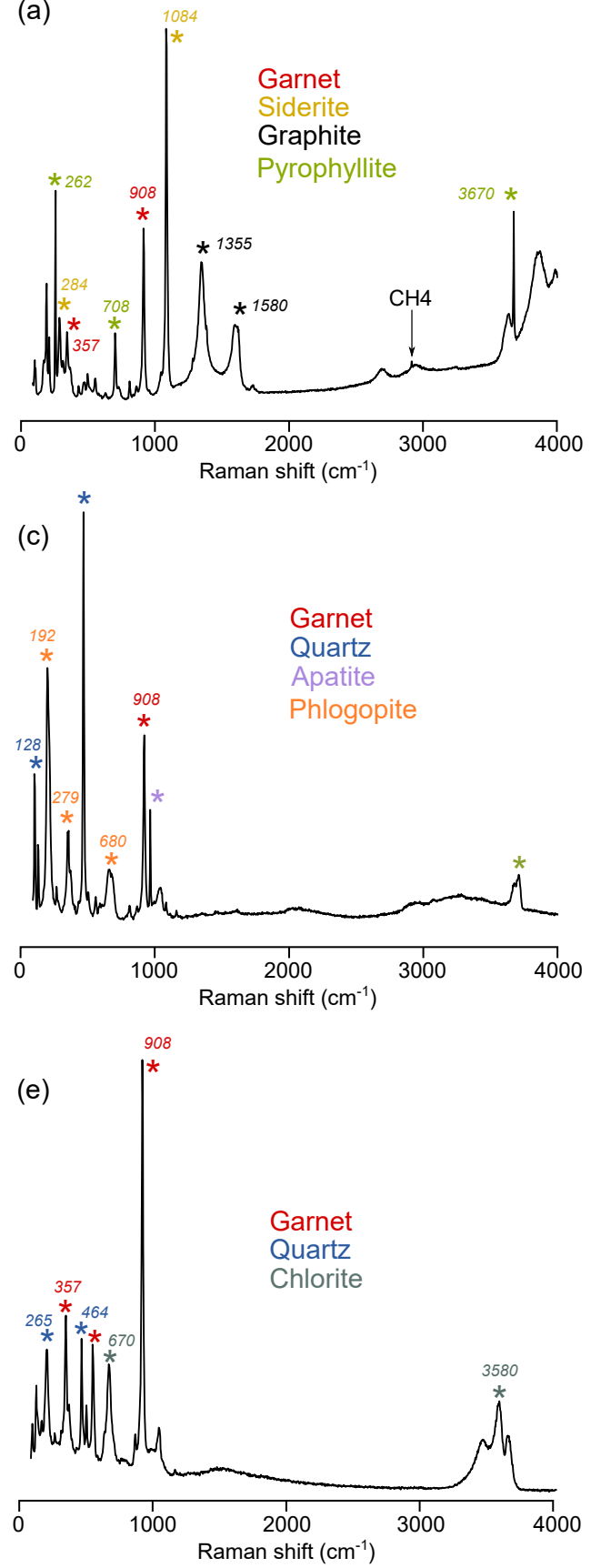

(b)

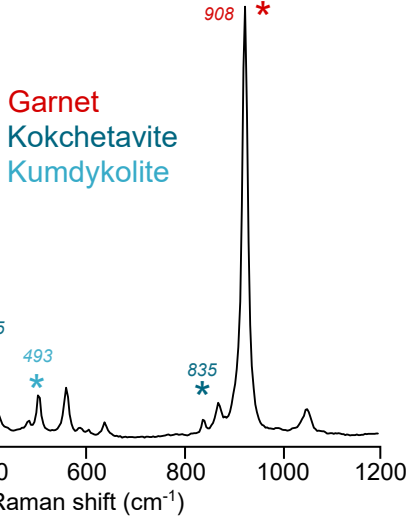

(d)
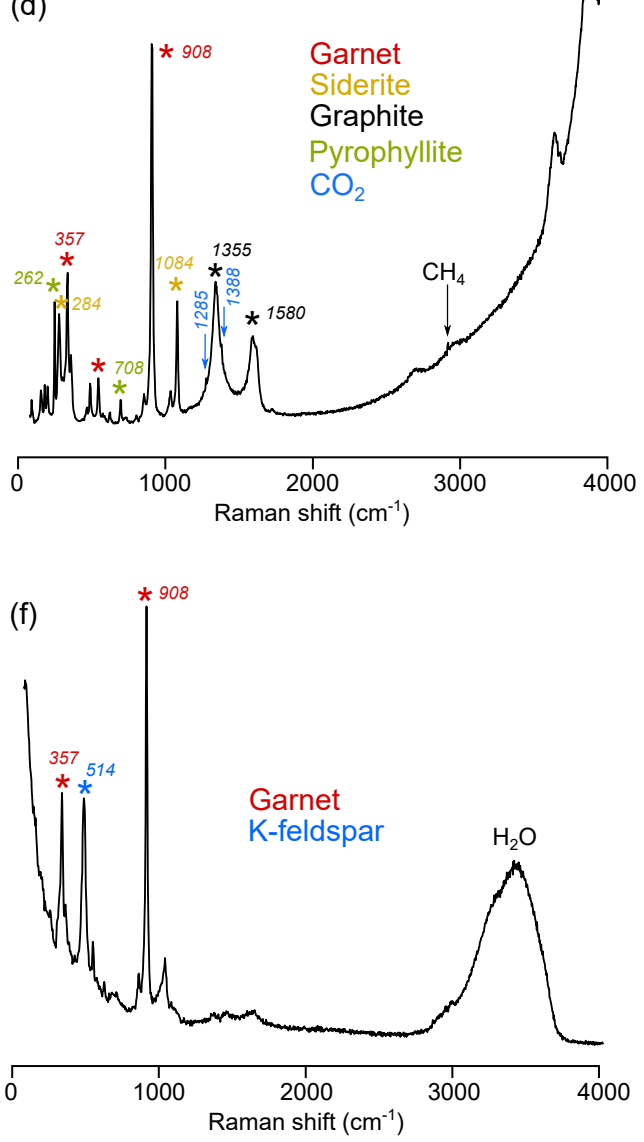

(g)

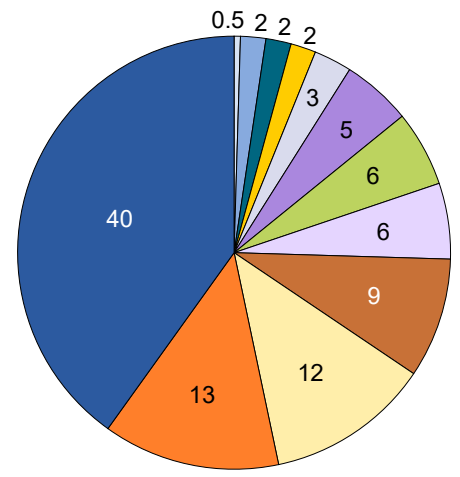

Grt ${ }^{1}$ Xenoblastic garnet

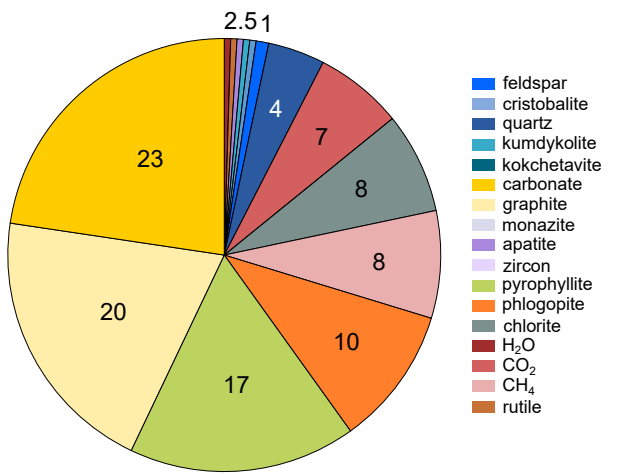

$\mathrm{Grt}^{2}$ Idioblastic garnet

Figure 3. Raman spectra of phases in preserved MI and FI. Figures (a) to (c) are from xenoblastic garnet (Grt ${ }^{1}$ ). (a) Fluid inclusion: mixed spectrum of garnet, siderite, pyrophyllite, graphite and $\mathrm{CH}_{4}$. (b-c) Melt inclusion: mixed spectra of garnet, kokchetavite and kumdykolite (b) and garnet, quartz, biotite and apatite (c). Figures (d) to (f) are from idioblastic garnet (Grt ${ }^{2}$ ). (d) Fluid inclusion: mixed spectrum of garnet, siderite, pyrophyllite, graphite, $\mathrm{CO}_{2}$ and $\mathrm{CH}_{4}$. (e-f) Melt inclusions: mixed spectra of garnet, quartz and chlorite (e) and garnet, $\mathrm{K}$-feldspar and $\mathrm{H}_{2} \mathrm{O}$ (f). (g) Statistical distribution of the different phases observed in inclusions in the two types of garnet. Number of analysed minerals and phases per garnet $=212$. 
net types $\mathrm{FI}$ contain $\mathrm{CO}_{2}+\mathrm{CH}_{4}+$ pyrophyllite +graphite +carbonates (mainly siderite, Fig. 3a,d), with quartz often present along with minor phlogopite. Neither $\mathrm{N}_{2}$ or liquid $\mathrm{H}_{2} \mathrm{O}$ were identified within the $\mathrm{FI}$ during Raman investigation.

Nanogranitoids in the two different types of garnet show different phase assemblages. In $\mathrm{Grt}^{1}$ they contain an assemblage consisting of quartz/cristobalite + kokchetavite + kumdykolite \pm phlogopite (Fig. 3b,c). In Grt they mostly consist of quartz +chlorite, with $\mathrm{H}_{2} \mathrm{O}$ locally present in one inclusion along with K-feldspar (Fig. 3e,f). Overall, the statistic distribution of the phases identified via Micro-Raman spectroscopy indicates that $~ 60 \%$ of the phases in $\mathrm{Grt}^{1}$ are characteristic of nanogranitoids (mainly quartz, phlogopite, cristobalite) or are accessory minerals (zircon, apatite, monazite, rutile) (Fig. 3g). Conversely, $\mathrm{Grt}^{2}$ contains both nanogranitoids and $\mathrm{FI}$, but its inclusion population is clearly dominated by the latter. About $85 \%$ of the spectra acquired on $\mathrm{Grt}^{2}$ show mineral phases associated to FI (carbonates, pyrophyllite, graphite) and volatiles species $\left(\mathrm{CO}_{2}, \mathrm{CH}_{4}\right)$, with the rest representing phases commonly found in nanogranitoids (e.g. quartz, feldspar and mica). Microprobe analyses (Table 1) show that both garnet types are in average Alm- and Prp-rich in the inclusion-bearing core with slightly variable Grs component (Grt': Alm ${ }^{10.8} \operatorname{Prp}_{23.4}$ Sps $_{1.9}$ Grs $_{3.9}$; $\mathrm{Grt}^{2}: \mathrm{Alm}_{71.2} \operatorname{Prp}_{23.1} \mathrm{Sps}_{2.0} \mathrm{Grs}_{3.7}$ ), which becomes significant in the light of the results of the thermodynamic modelling on these rocks (see below).

\section{Metamorphic conditions}

We used phase equilibria modelling (Perple_X - Connolly 2009) with the bulk-rock composition and mineral abundance of the metapelite KS97 described by Kays et al. (1989) and the bulk and garnet compositions of sample 589590 (Table 2) to reassess the metamorphic conditions of the Uttental plateau Archean suite (Fig. 4).

Table 1. Garnet composition.

\begin{tabular}{|c|c|c|c|c|c|c|c|c|c|c|}
\hline Garnet & 1 & 1 & 1 & 1 & 1 & 1 & 2 & 2 & 2 & 2 \\
\hline Location & core & core & core & core & rim & rim & core & core & rim & rim \\
\hline $\mathrm{SiO}_{2}$ & 38.31 & 38.11 & 38.21 & 38.11 & 38.20 & 38.32 & 37.99 & 37.94 & 37.71 & 37.77 \\
\hline $\mathrm{TiO}_{2}$ & 0.02 & 0.03 & 0.00 & 0.00 & 0.04 & 0.04 & 0.04 & 0.02 & 0.01 & 0.02 \\
\hline $\mathrm{Al}_{2} \mathrm{O}_{3}$ & 22.00 & 21.81 & 21.81 & 21.69 & 21.89 & 21.91 & 22.06 & 21.84 & 21.95 & 21.51 \\
\hline $\mathrm{FeO}$ & 32.36 & 32.08 & 32.83 & 32.92 & 32.46 & 32.99 & 32.60 & 32.56 & 32.40 & 33.59 \\
\hline $\mathrm{MnO}$ & 0.85 & 0.92 & 0.87 & 0.88 & 0.94 & 0.91 & 0.93 & 0.92 & 0.91 & 0.95 \\
\hline $\mathrm{MgO}$ & 6.28 & 6.17 & 6.00 & 5.68 & 6.22 & 5.83 & 6.09 & 5.95 & 5.70 & 5.19 \\
\hline $\mathrm{CaO}$ & 1.30 & 1.51 & 1.32 & 1.40 & 1.12 & 1.28 & 1.18 & 1.31 & 1.42 & 1.45 \\
\hline $\mathrm{Na}_{2} \mathrm{O}$ & 0.01 & 0.04 & 0.00 & 0.02 & 0.00 & 0.01 & 0.02 & 0.01 & 0.04 & 0.00 \\
\hline $\mathrm{K}_{2} \mathrm{O}$ & 0.01 & 0.00 & 0.00 & 0.01 & 0.01 & 0.00 & 0.00 & 0.00 & 0.00 & 0.01 \\
\hline $\mathrm{Cr}_{2} \mathrm{O}_{3}$ & 0.06 & 0.10 & 0.00 & 0.00 & 0.09 & 0.04 & 0.02 & 0.02 & 0.02 & 0.06 \\
\hline Total & 101.20 & 100.78 & 101.03 & 100.71 & 100.95 & 101.33 & 100.91 & 100.57 & 100.14 & 100.56 \\
\hline $\mathrm{Si}$ & 2.98 & 2.98 & 2.99 & 2.99 & 2.98 & 2.99 & 2.97 & 2.98 & 2.97 & 2.99 \\
\hline $\mathrm{Ti}$ & 0.00 & 0.00 & 0.00 & 0.00 & 0.00 & 0.00 & 0.00 & 0.00 & 0.00 & 0.00 \\
\hline Al & 2.02 & 2.01 & 2.01 & 2.01 & 2.02 & 2.01 & 2.03 & 2.02 & 2.04 & 2.00 \\
\hline $\mathrm{Fe}$ & 2.11 & 2.10 & 2.15 & 2.16 & 2.12 & 2.15 & 2.13 & 2.14 & 2.14 & 2.22 \\
\hline $\mathrm{Mn}$ & 0.06 & 0.06 & 0.06 & 0.06 & 0.06 & 0.06 & 0.06 & 0.06 & 0.06 & 0.06 \\
\hline $\mathrm{Mg}$ & 0.73 & 0.72 & 0.70 & 0.66 & 0.72 & 0.68 & 0.71 & 0.70 & 0.67 & 0.61 \\
\hline $\mathrm{Ca}$ & 0.11 & 0.13 & 0.11 & 0.12 & 0.09 & 0.11 & 0.10 & 0.11 & 0.12 & 0.12 \\
\hline Alm & 70.22 & 69.82 & 71.22 & 71.99 & 70.68 & 71.82 & 71.01 & 71.14 & 71.54 & 73.55 \\
\hline Pyr & 24.30 & 23.95 & 23.21 & 22.13 & 24.13 & 22.61 & 23.65 & 23.15 & 22.42 & 20.26 \\
\hline Sps & 1.86 & 2.02 & 1.92 & 1.96 & 2.08 & 2.00 & 2.06 & 2.04 & 2.03 & 2.11 \\
\hline Grs & 3.62 & 4.21 & 3.66 & 3.92 & 3.11 & 3.56 & 3.28 & 3.67 & 4.02 & 4.08 \\
\hline
\end{tabular}

$\mathrm{Alm}=100 \times \mathrm{Fe} /(\mathrm{Fe}+\mathrm{Mg}+\mathrm{Ca}+\mathrm{Mn})$

$\operatorname{Prp}=100 \times \mathrm{Mg} /(\mathrm{Fe}+\mathrm{Mg}+\mathrm{Ca}+\mathrm{Mn})$

$\mathrm{Sps}=100 \times \mathrm{Mn} /(\mathrm{Fe}+\mathrm{Mg}+\mathrm{Ca}+\mathrm{Mn})$

$\mathrm{Grs}=100 \times \mathrm{Ca} /(\mathrm{Fe}+\mathrm{Mg}+\mathrm{Ca}+\mathrm{Mn})$ 
Table 2. Bulk rock compositions in wt\%.

\begin{tabular}{ccc}
\hline Sample & KS97* & 589590 \\
\hline $\mathrm{SiO}_{2}$ & 55.94 & 67.66 \\
$\mathrm{TiO}_{2}$ & 0.73 & 0.32 \\
$\mathrm{Al}_{2} \mathrm{O}_{3}$ & 23.48 & 15.01 \\
$\mathrm{Fe}_{2} \mathrm{O}_{3}$ & 2.27 & 0.72 \\
$\mathrm{FeO}$ & 5.83 & 5.30 \\
$\mathrm{MnO}$ & 0.05 & 0.14 \\
$\mathrm{MgO}$ & 4.12 & 1.32 \\
$\mathrm{CaO}$ & 1.19 & 1.17 \\
$\mathrm{Na}_{2} \mathrm{O}$ & 1.44 & 2.46 \\
$\mathrm{~K}_{2} \mathrm{O}$ & 2.13 & 5.55 \\
$\mathrm{P}_{2} \mathrm{O}_{5}$ & 0.05 & 0.03 \\
\hline
\end{tabular}

*Kays et al. (1989)

Phase equilibria modelling was undertaken in the chemical system $\mathrm{MnO}-\mathrm{Na}_{2} \mathrm{O}-\mathrm{CaO}-\mathrm{K}_{2} \mathrm{O}-\mathrm{FeO}-\mathrm{MgO}-\mathrm{Al}_{2} \mathrm{O}_{3}-$ $\mathrm{SiO}_{2}-\mathrm{H}_{2} \mathrm{O}-\mathrm{TiO}_{2}-\mathrm{O}_{2}$ (MnNCKFMASHTO) with Holland and Powell (1998) thermodynamic database with 2004 updates. The following $a-x$ models were used: garnet, biotite, cordierite, orthopyroxene, muscovite, chlorite, ilmenite, melt (White et al. 2014), feldspar (Fuhrman, Lindsley 1988), and magnetite (White et al. 2002). Bulkrock water content, 0.74 wt\% for KS97 and 0.9 wt\% for

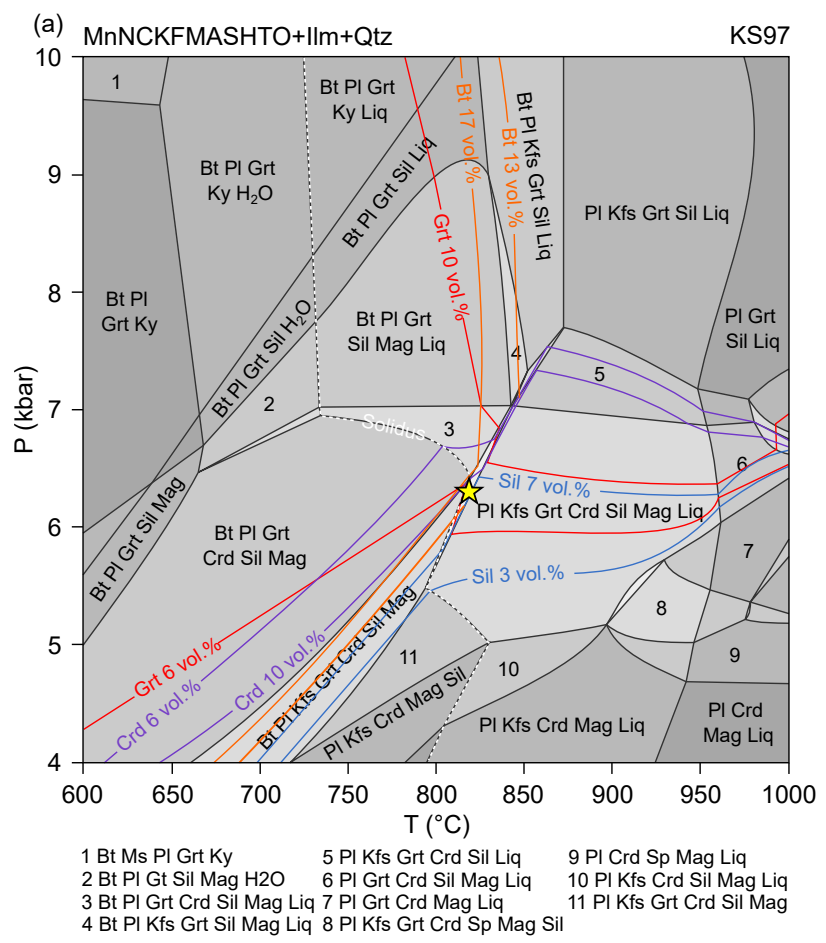

589590, was fixed to solidus statured values using $\mathrm{T}-\mathrm{H}_{2} \mathrm{O}$ reconnaissance modelling at $6 \mathrm{kbar}$.

Sample KS97 is a metapelite characterised by the metamorphic assemblage Grt (8) + Bt (15) + Crd (8) + Sil (5) $+\mathrm{Pl}(19)+\mathrm{Kfs}(12)+\mathrm{Mag}(2.5)+\mathrm{Ilm}(1)+\mathrm{Qtz} \pm \mathrm{Ms}$ (number in brackets indicate the modal abundance in vol.\% - Kays et al. 1989). This assemblage is stable between $800-850^{\circ} \mathrm{C}$ and $5.5-7.0 \mathrm{kbar}$ (Fig. 4a). The modelling indicates that the observed assemblage is likely to preserve subsolidus to solidus conditions. Mineral abundances provide a more detailed estimate. They indicate that the preserved metamorphic conditions for the assemblage are $\sim 825^{\circ} \mathrm{C}$ and $6.5 \mathrm{kbar}$ (Fig. 4a).

Suprasolidus peak metamorphic conditions for sample 589590 are given by garnet compositions (see Table 1). Our modelling indicates that $\mathrm{Grt}^{1}$ (Grs: 3-4 and Prp: 2324 ) is stable at $950-1000^{\circ} \mathrm{C}$ and $6-8 \mathrm{kbar}$, whereas $\mathrm{Grt}^{2}$ (Grs: $3.5-4$ and Prp: $21-23$ ) is stable at $825-950^{\circ} \mathrm{C}$ and 5.5-7.0 kbar (Fig. 4b). At these conditions, the modelled mineral assemblage Grt $+\mathrm{Pl}+\mathrm{Ilm}+\mathrm{Qtz}+\mathrm{Liq} \pm \mathrm{Mag} \pm$ $\mathrm{Kfs} \pm \mathrm{Bt} \pm$ Opx matches the observed assemblage. The abundance of Opx in these fields is $<1$ vol.\%.

\section{Discussion and perspectives}

Our study targeting $\mathrm{MI}$ and FI provides new data on the evolution of the metapelites of the Uttental plateau in

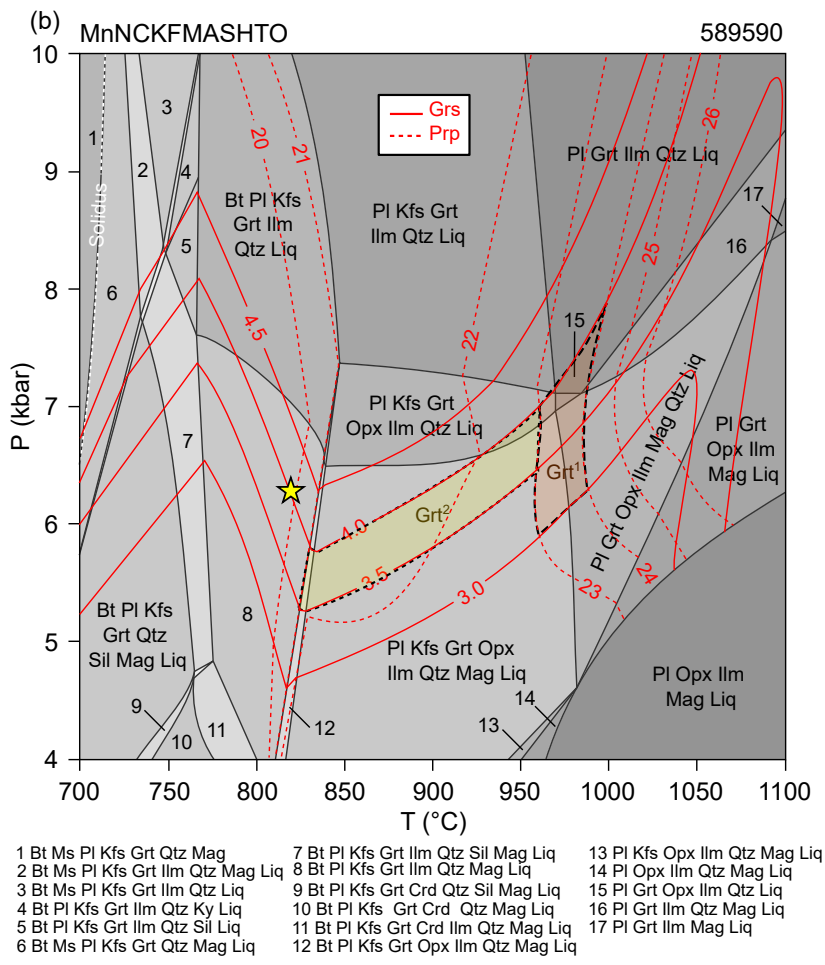

Figure 4. (a) Calculated P-T pseudosection for KS97 (Kays et al. 1980) in the MnNCKFMASHTO system. Stability field for the preserved metamorphic assemblage $\mathrm{Grt}+\mathrm{Bt}+\mathrm{Crd}+\mathrm{Pl}+\mathrm{Kfs}+\mathrm{Ilm}+\mathrm{Mag}+\mathrm{Sil} \pm \mathrm{Qtz}+\mathrm{Liq}$. The star indicates the P-T conditions at which observed abundances match modelled ones. We assumed a \pm 2 vol.\% error on the published abundance by Kays et al. (1989). (b) Calculated P-T pseudosection for 589590 in the MnNCKFMASHTO system. The stability field for the preserved metamorphic assemblage given by $\mathrm{Grt}^{1}$ is $\mathrm{Grt}+\mathrm{PI}+\mathrm{Ilm}+\mathrm{Qtz}+\mathrm{Liq} \pm \mathrm{Mag} \pm \mathrm{Kfs} \pm \mathrm{Opx}$. The stability field for the preserved metamorphic assemblage given by $\mathrm{Grt}^{2}$ is $\mathrm{Grt}+\mathrm{PI}+\mathrm{Ilm}+\mathrm{Qtz}+\mathrm{Liq}+\mathrm{Mag}+\mathrm{Kfs} \pm \mathrm{Opx} \pm \mathrm{Bt}$. The star indicates the conditions determined for KS97. 
Southeast Greenland by merging results from host rock petrography, Micro-Raman spectroscopy, statistical distribution of the phases in inclusions in garnet and phase equilibria modelling.

The first notable outcome is that these metasediments experienced partial melting during their metamorphic history. Previous estimates indicated peak metamorphic conditions at $650-700^{\circ} \mathrm{C}$ and $3-4$ kbar. However, these calculations were solely based on Fe-Mg exchange thermobarometers (Kays et al. 1989 and references therein) and are then likely to reflect re-equilibration in the later stage of the retrograde path. Our P-T conditions indicate peak metamorphism at $950-1000^{\circ} \mathrm{C}$ and $>7 \mathrm{kbar}$ and retrograde conditions of $\sim 800^{\circ} \mathrm{C}$ and $6 \mathrm{kbar}$. Although located further to the north, these are similar to estimates Yakymchuk et al. (2020) obtained for the Akia Terrane (ca. $3.0 \mathrm{Ga}$ ) in West Greenland, $>800^{\circ} \mathrm{C}$ and $<9$ kbar. Due to the lack of deformation and the presence of tonalitic magma, these authors suggested that such metamorphic conditions might reflect growth and differentiation of the crust in a stagnant-lid tectonic regime. Still in West Greenland, Kirkland et al. (2018) also showed that the Kangerlussuaq Supracrustal Belt in the Akia terrane has undergone partial melting and ductile deformation during a prolonged metamorphic event, $820-850^{\circ} \mathrm{C}$ and $8-10 \mathrm{kbar}$, between $2700-2857 \mathrm{Ma}$, consistent with a convergent margin in a mobile-lid tectonic regime. Hence, there is a need for more accurate pressure-temperature-time paths on the rocks exposed in the southeastern coast of Greenland. In addition, the recent discovery of 2900-3100 Ma orthogneisses in the Paleoprotoerzoic Rinkian Belt, West Greenland (Thrane, 2021) calls for a reevaluation of the extend of terrane boundaries between East and West Greenland, as well as Canada. A comprehensive picture of the evolution of the felsic basement and the supracrustal rocks in the Uttental Plateau would play a key role in connecting orogenic events on both sides of the icecap.

The second crucial point is that garnets in these migmatites contain $\mathrm{Fl}$ and nanogranitoids. The distribution of these inclusions in both $\mathrm{Grt}^{1}$ and $\mathrm{Grt}^{2}$ is primary, thus suggesting that both garnet types are peritectic in nature, i.e. they grew in presence of melt, likely as direct result of the partial melting reaction (Cesare et al. 2015). Moreover, the fact that $\mathrm{Fl}$ and nanogranitoids occur in the same clusters testifies for the growth of both garnet types to have occurred under conditions of fluid-melt immiscibility (e.g. Ferrero et al. 2014; 2016; Carvalho et al. 2019; Gianola et al. 2021), in presence of a $\mathrm{COH}$-fluid. To date, this case study presents the oldest case study of nanogranitoids as well as the first verified instance of partial melting in presence of a $\mathrm{COH}$-fluid in Mesoarchean crustal rocks.
Such $\mathrm{COH}$-fluid is likely to be externally derived, as an internal origin would require the presence of graphite, which is notably absent as rock-forming mineral in the studied samples (see also discussion in Carvalho et al. 2019). Here, graphite is present exclusively in the $\mathrm{FI}$ where it can be interpreted as the result of post-entrapment respeciation of the $\mathrm{COH}$ fluid (Cesare et al. 2007). Similarly, most of the mineral phases observed in the investigated FI (i.e. pyrophyllite, carbonates, quartz and phlogopite) were not present during inclusion formation but are to be considered as stepdaughter minerals resulting from the interaction of the trapped $\mathrm{COH}$-fluid and the host/garnet during cooling, in analogy with the recent work of Carvalho et al. (2020).

Raman spectroscopy and petrographic characterisation of the pairs host/inclusions allowed us to also draw more detailed conclusions on the suprasolidus history of the investigated sample. The phase assemblage visible in the nanogranitoid is clearly different between $\mathrm{Grt}^{1}$ and $\mathrm{Grt}^{2}$. In $\mathrm{Grt}^{1}$ the melt crystallises to quartz/cristobalite + kokchetavite + kumdykolite \pm phlogopite, whereas in $\mathrm{Grt}^{2}$ the nanogranitoids often contain chlorite (already found in primary, crack-free nanogranitoids by Bartoli et al. 2019) and occasionally $\mathrm{H}_{2} \mathrm{O}$. This suggests that $\mathrm{Grt}^{1}$ and $\mathrm{Grt}^{2}$ contain two different melts, melt $^{1}$ and melt ${ }^{2}$ respectively. Interestingly, the association nanogranitoids + rutile needles visible exclusively in $\mathrm{Grt}^{1}$ was recently reported by Ferrero et al. $(2021 \mathrm{a}, \mathrm{b})$ in case studies of nanogranitoids formed at $\mathrm{T} \sim 1000^{\circ} \mathrm{C}$, possibly pointing toward a higher formation $\mathrm{T}$ for the pair $\mathrm{melt}^{1} / \mathrm{Grt}^{1}$ with respect to melt ${ }^{2} / \mathrm{Grt}^{2}$, as already suggested by the modelling. Further studies involving experimental re-homogenisation using a piston cylinder press (see e.g. Ferrero et al. 2021 a) will clarify in detail compositions and P-T formation conditions of the two different melts.

We reiterate here the message that anatectic melt and fluid inclusions are quite common in granulitic rocks but have been majorly overlooked (Nicoli, Ferrero 2021). This aspect, combined with the preservation and full exposure of the outcrops, makes the southeastern coast of Greenland a perfect geological playground for researchers aiming to understand crustal growth, reworking and volatile recycling at the dawn of plate tectonics.

\section{Acknowledgements}

The authors would like to thank J. Majka for the handling of the manuscript as well as B.B. Carvalho, M. Janák and an anonymous reviewer for their comments. Fieldwork was supported by the Natural Environment Research Council (NE/N009894/1) and the Geological Survey of Denmark and Greenland. This research was supported through the Alexander von Humboldt Foundation to GN and by the German Federal Ministry for Education and 
Research, as well as the Deutsche Forschungsgemeinschaft (Project FE 1527/2-3) to SF.

\section{Conflicts of interest}

The authors have no conflicts of interests to declare.

\section{References}

Bartoli, O., Acosta-Vigil, A., Ferrero, S., \& Cesare, B. (2016). Granitoid magmas preserved as melt inclusions in high-grade metamorphic rock. American Mineralogist, 101(7), 1543-1559. https://doi.org/10.2138/am-20165541CCBYNCND

Bufe, N. A., Holness, M. B., \& Humphreys, M. C. (2014). Contact metamorphism of Precambrian gneiss by the Skaergaard Intrusion. Journal of Petrology, 55(8), 15951617. https://doi.org/10.1093/petrology/egu035

Carvalho, B. B., Bartoli, O., Ferri, F., Cesare, B., Ferrero, S., Remusat, L., ... \& Poli, S. (2019). Anatexis and fluid regime of the deep continental crust: New clues from melt and fluid inclusions in metapelitic migmatites from Ivrea Zone (NW Italy). Journal of Metamorphic Geology, 37(7), 951-975. https://doi.org/10.1111/ jmg.12463

Carvalho, B. B., Bartoli, O., Cesare, B., Tacchetto, T., Gianola, O., Ferri, F., ... \& Szabó, C. (2020). Primary $\mathrm{CO}_{2}$-bearing fluid inclusions in granulitic garnet usually do not survive. Earth and Planetary Science Letters, 536, 116170. https://doi.org/10.1016/j.epsl.2020.116170

Cesare, B., Acosta-Vigil, A., Bartoli, O., \& Ferrero, S. (2015). What can we learn from melt inclusions in migmatites and granulites?. Lithos, 239, 186-216. https://doi. org/10.1016/j.lithos.2015.09.028

Cesare, B., Maineri, C., Toaldo, A. B., Pedron, D., \& Vigil, A. A. (2007). Immiscibility between carbonic fluids and granitic melts during crustal anatexis: A fluid and melt inclusion study in the enclaves of the Neogene Volcanic Province of SE Spain. Chemical Geology, 237, 433449. https://doi.org/10.1016/j.chemgeo.2006.07.013

Connolly, J. A. D. (2009). The geodynamic equation of state: what and how. Geochemistry, Geophysics, Geosystems, 10(10). https://doi.org/10.1029/2009GC002540

Dhuime, B., Hawkesworth, C. J., Delavault, H., \& Cawood, P. A. (2018). Rates of generation and destruction of the continental crust: implications for continental growth. Philosophical Transactions of the Royal Society A: Mathematical, Physical and Engineering Sciences, 376(2132), 20170403. https://doi.org/10.1098/rsta.2017.0403

Ferrero, S., Ague, J. J., O’Brien, P. J., Wunder, B., Remusat, L., Ziemann, M. A., \& Axler, J. (2021a). High-pressure, halogen-bearing melt preserved in ultrahigh-temperature felsic granulites of the Central Maine Terrane, Connecticut (USA). American Mineralogist, 106(8), 12251236. https://doi.org/10.2138/am-2021-7690

Ferrero, S., Braga, R., Berkesi, M., Cesare, B., \& Laridhi Ouazaa, N. (2014). Production of metaluminous melt during fluid-present anatexis: an example from the Maghrebian basement, La Galite Archipelago, central Mediterranean. Journal of Metamorphic Geology, 32(2), 209225. https://doi.org/10.1111/jmg.12068
Ferrero, S., Wannhoff, I., Laurent, O., Yakymchuk, C., Darling, R., Wunder, B., ... \& O’Brien, P. J. (2021b). Embryos of TTGs in Gore Mountain garnet megacrysts from water-fluxed melting of the lower crust. Earth and Planetary Science Letters, 569, 117058. https://doi. org/10.1016/j.epsl.2021.117058

Ferrero, S., Wunder, B., Ziemann, M. A., Wälle, M., \& O’Brien, P. J. (2016). Carbonatitic and granitic melts produced under conditions of primary immiscibility during anatexis in the lower crust. Earth and Planetary Science Letters, 454, 121-131. https://doi.org/10.1016/j. epsl.2016.08.043

Fuhrman, M. L., \& Lindsley, D. H. (1988). Ternary-feldspar modeling and thermometry. American Mineralogist, 73(3-4), 201-215.

Gianola, O., Bartoli, O., Ferri, F., Galli, A., Ferrero, S., Capizzi, L. S., ... \& Cesare, B. (2021). Anatectic melt inclusions in ultra high temperature granulites. Journal of Metamorphic Geology, 39(3), 321-342. https://doi. org/10.1111/jmg.12567

Holland, T. J. B., \& Powell, R. T. J. B. (1998). An internally consistent thermodynamic data set for phases of petrological interest. Journal of metamorphic Geology, 16(3), 309-343. https://doi.org/10.1111/j.15251314.1998.00140.x

Holwell, D. A., Jenkin, G. R. T., Butterworth, K. G., Abraham-James, T., \& Boyce, A. J. (2013). Orogenic gold mineralisation hosted by Archaean basement rocks at Sortekap, Kangerlussuaq area, East Greenland. Mineralium Deposita, 48(4), 453-466. https://doi. org/10.1007/s00126-012-0434-3

Kays, M. A., Goles, G. G., \& Grover, T. W. (1989). Precambrian sequence bordering the Skaergaard Intrusion. Journal of Petrology, 30(2), 321-361. https://doi.org/10.1093/ petrology/30.2.321

Kirkland, C. L., Yakymchuk, C., Hollis, J., Heide-Jørgensen, H., \& Danišík, M. (2018). Mesoarchean exhumation of the Akia terrane and a common Neoarchean tectonothermal history for West Greenland. Precambrian Research, 314, 129-144.

Kretz, R. (1983). Symbols for rock-forming minerals. American Mineralogist, 68(1-2), 277-279.

Leeman, W. P., Dasch, E. J., \& Kays, M. A. (1976). ${ }^{207} \mathrm{~Pb} /{ }^{206} \mathrm{~Pb}$ whole-rock age of gneisses from the Kangerdlugssuaq area, eastern Greenland. Nature, 263(5577), 469-471.

Nicoli, G., \& Ferrero, S. (2021). Nanorocks, volatiles and plate tectonics. Geoscience Frontiers, 12(5), 101188. https:// doi.org/10.1016/j.gsf.2021.101188

Nicoli, G., Thomassot, E., Schannor, M., Vezinet, A., \& Jovovic, I. (2018). Constraining a Precambrian Wilson Cycle lifespan: an example from the ca. $1.8 \mathrm{Ga}$ Nagssugtoqidian Orogen, Southeastern Greenland. Lithos, 296, 1-16. https://doi.org/10.1016/j.lithos.2017.10.017

Nicoli, G., Moyen, J. F., \& Stevens, G. (2016). Diversity of burial rates in convergent settings decreased as Earth aged. Scientific Reports, 6(1), 1-10. doi: 10.1038/srep26359

Palin, R. M., Santosh, M., Cao, W., Li, S. S., Hernández-Uribe, D., \& Parsons, A. (2020). Secular change and the onset of plate tectonics on Earth. Earth-Science Reviews, 207, 103172. https://doi.org/10.1016/j. earscirev.2020.103172 
Tacchetto, T., Bartoli, O., Cesare, B., Berkesi, M., Aradi, L. E., Dumond, G., \& Szabó, C. (2019). Multiphase inclusions in peritectic garnet from granulites of the Athabasca granulite terrane (Canada): Evidence of carbon recycling during Neoarchean crustal melting. Chemical Geology, 508, 197-209. https://doi.org/10.1016/j. precamres.2021.106139

Thrane, K. (2021). The oldest part of the Rae craton identified in western Greenland. Precambrian Research, 357, 106139. https://doi.org/10.1016/j. precamres.2021.106139

Wager, L. R. (1934). Geological Investigations in East Greenland. (Vol. 105, No. 2-3). CA Reitzels forlag.

Wager, L. R., \& Deer, W. A. (1939). Geological investigations in East Greenland, Part IV. Medde lelser om Grønland, 134(5).

White, R. W., Powell, R., \& Clarke, G. L. (2002). The interpretation of reaction textures in Fe-rich metapelitic granulites of the Musgrave Block, central Australia: constraints from mineral equilibria calculations in the system $\mathrm{K}_{2} \mathrm{O}-\mathrm{FeO}-\mathrm{MgO}-\mathrm{Al}_{2} \mathrm{O}_{3}-\mathrm{SiO}_{2}-\mathrm{H}_{2} \mathrm{O}-\mathrm{TiO}_{2}-\mathrm{Fe}_{2} \mathrm{O}_{3}$. Journal of metamorphic Geology, 20(1), 41-55. https:// doi.org/10.1046/j.0263-4929.2001.00349.x

White, R. W., Powell, R. Holland, T. J. B., Johnson, T. E., \& Green, E. C. R. (2014). New mineral activity-composition relations for thermodynamic calculations in metapelitic systems. Journal of Metamorphic Geology, 32(3), 261-286. https://doi.org/10.1111/jmg.12071

Yakymchuk, C., Kirkland, C. L., Hollis, J. A., Kendrick, J., Gardiner, N. J., \& Szilas, K. (2020). Mesoarchean partial melting of mafic crust and tonalite production during high-T-low-P stagnant tectonism, Akia Terrane, West Greenland. Precambrian Research, 339, 105615. https://doi.org/10.1016/j.precamres.2020.105615

Received: 18 November 2021

Accepted: 12 January 2022

Handling Editor: Jarosław Majka 